\title{
KOMPETENSI GURU PENDIDIKAN ISLAM DALAM PENGELOLAAN PEMBELAJARAN DI MADRASAH ALIYAH AS'ADIYAH PUTERI SENGKANG KABUPATEN WAJO
}

\author{
Falihal Hairi \\ Pascasarjana UIN Alauddin Makassar \\ JL.H.M Yasin Limpo No. 36 Samata, Gowa \\ Email: falihalhairi23@yahoo.com
}

\begin{abstract}
Abstrak
Hasil penelitian menunjukkan bahwa 1) Kompetensi pedagogik guru pendidikan Islam di Madrasah Aliyah As'adiyah Puteri Sengkang Kabupaten Wajo belum maksimal, yang berkaitan dengan tugas fungsinya sebagai guru, guru hendaknya menguasai teori belajar dan prinsip kegiatan pembelajaran, dan mampu menerapkan berbagai pendekatan, strategi, metode, dan teknik pembelajaran yang mendidik secara kreatif dalam mata pelajaran yang diampuh. 2) Guru pendidikan Islam dalam pengelolaan pembelajaran di Madrasah Aliyah As'adiyah Puteri Sengkang Kabupaten Wajo, masih diperlukan efektivitas yang lebih optimal agar keberhasilan pembelajaran dapat tercapai dengan baik dan operasional guru mata pelajaran pendidikan Islam, terlihat dari upaya guru untuk melaksanakan perencanaan, pelaksanaan dan evaluasi terutama yang berkenaan dengan perangkat pembelajaran, diperlukan model pembelajaran sesuai dengan tuntutan isi dan hasil yang diharapkan. 3) Faktor pendukung guru pendidikan Islam dalam pengelolaan pembelajaran di Madrasah Aliyah As'adiyah Puteri Sengkang yaitu ketersediaan perangkat pembelajaran, prasarana Madrasah, dan fungsi yang mendukung kegiatan pembelajaran. Faktor penghambat guru pendidikan Islam dalam pengelolaan pembelajaran di Madrasah Aliyah As'adiyah Puteri Sengkang yaitu keterbatasan jam pelajaran, kedisiplinan guru dan sarana belajar Madrasah.

Kata Kunci: Kompetensi guru pendidikan Islam dalam pengelolaan pembelajaran
\end{abstract}

\section{PENDAHULUAN}

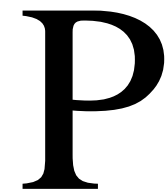

endidikan Islam adalah pendidikan yang bertujuan untuk membentuk pribadi muslim seutuhnya, mengembangkan seluruh potensi manusia baik yang berbentuk jasmaniyah maupun rohaniyah, menumbuhkan hubungan yang harmonis setiap pribadi manusia dengan Allah, manusia dengan manusia, manusia dan Alam semesta. Pendidikan Islam mengajarkan setiap manusia umumnya dan umat Islam khususnya untuk mencapai dan mewujudkan tujuan yang sesungguhnya yaitu untuk selalu taat dan mengabdi kepada Allah swt. Tujuan ini merupakan dasar yang paling utama sebagai bentuk pengabdian seorang hamba kepada Tuhannya. ${ }^{1}$ Banyak dalil al-Qur'a>n yang mengisyaratkan peran para nabi dan pengikutnya dalam pendidikan dan fungsi fundamental dalam pengkajian ilmu Ilahiyah dan pengaplikasiannya. Keutamaan profesi guru sangat besar sehingga Allah swt., \footnotetext{
2009), h. 6.

${ }^{1}$ Haidar Putra Daulay, Pemberdayaan Pendidikan Islam di Indonesia (Jakarta; Rineka Cipta,
} 
menjadikan sebagai tugas yang diemban oleh Rasulullah saw., sebagaimana diisyaratkan dalam QS. Ali 'Imran ayat 164.

Terjemahnya :

Sungguh Allah telah memberi karunia kepada orang-orang yang beriman ketika Allah mengutus di antara mereka seorang Rasul dari golongan mereka sendiri, yang membacakan kepada mereka ayat-ayat Allah, membersihkan (jiwa) mereka, dan mengajarkan kepada mereka al Kitab dan al Hikmah. dan Sesungguhnya sebelum (kedatangan Nabi) itu, mereka adalah benar-benar dalam kesesatan yang nyata. ${ }^{2}$

Ketika Allah mengutus di antara mereka, yakni untuk mereka seorang rasul dari kalangan mereka sendiri, yakni jenis manusia, yang mereka kenal kejujuran dan amanahnya, kecerdasan kemuliaan sebelum kenabian yang berfungsi terus-menerus membacakan kepada mereka ayat-ayat Allah, berfungsi, baik dalam bentuk wahyu yang Engkau turunkan maupun alam raya yang Engkau ciptakan, dan terus menyucikan jiwa mereka dari segala macam kekotoran, kemunafikan, dan penyakitpenyakit jiwa melalui bimbingan dan tuntunan, lagi terus mengajarkan kepada mereka kandungan al-kita>b, yakni al-Qur'a $>n$ atau tulis baca, dan al-Hikmah, yakni asSunnah atau kebijakan dan kemahiran melaksanakan hal yang mendatangkan manfaat serta menampik mudharat. Kata terus, pada terjemahan tersebut, dipahami dari bentuk kata kerja masa kini dan datang yang digunakannya. Dan sesungguhnya keadaan mereka sebelum itu adalah benar-benar dalam kesesatan yang nyata. Sedemikian nyata sehingga jelas bagi setiap orang yang menggunakan walau secercah akal atau nuraninya. $^{3}$

Ayat tersebut menggambarkan fungsi guru, antara lain, berfungsi sebagai penyuci; artinya seorang guru berfungsi sebagai pembersih diri, pemelihara diri, pengembang, dan pemelihara fitrah manusia serta juga berfungsi sebagai pengajar; artinya seorang guru bertugas menyampaikan ilmu pengetahuan dan berbagai keyakinan kepada manusia agar menerapkan seluruh pengetahuannya dalam kehidupan sehari-hari. $^{4}$

Pengembangan kompetensi pedagogik guru mencakup empat kompetensi inti guru, yaitu:

1. Menguasai karakteristik peserta didik pada aspek fisik, moral, sosial, kultural, emosional, dan intelektual

2. Menguasai teori belajar dan prinsip-prinsip pembelajaran yang mendidik

3. Mengembangkan kurikulum yang terkait dengan mata pelajaran bidang pengembangan yang diampuh.

\footnotetext{
${ }^{2}$ Kementerian Agama RI., al-Qur'a $>n$ dan Terjemahnya (Bekasi: PT. Ikrar Mandiri Abadi, 2016), h. 104.

${ }^{3}$ M. Quraish Shihab, Tafsir al-Mishbah (Jakarta; Lentera Hati, 2002), h. 323.

${ }^{4}$ Abdurrahman al-Nahd \}awi, Pendidikan Islam di Rumah, Sekolah dan Masyarakat (Cet. IV; Jakarta: Gema Insani, 2004), h. 170.
} 
4. Penyelenggaraan pembelajaran yang mendidik. ${ }^{5}$

\section{METODE PENELITIAN}

Dalam menganalisis data, penulis menelaah seluruh data yang tersedia dari berbagai sumber, yaitu pengamatan yang sudah dituliskan dalam catatan lapangan, wawancara, dan dukumen pendukung. analisis data dalam penelitian ini dilakukan dalam tiga cara, yaitu: reduksi data, display data, kesimpulan dan verifikasi.

Jenis penelitian yang digunakan dalam penelitian ini adalah penelitian kualitatif deskriptif dengan mengambil lokasi dan objek penelitian pada penyelengaraan pendidikan Muslim Tionghoa di Kota Makassar.

\section{HASIL DAN PEMBAHASAN PENELITIAN}

\section{A. Kompetensi Guru Pendidikan Islam di Madrasah Aliyah As'adiyah Puteri Sengkang Kabupaten Wajo}

Komponen pendidikan di Madrasah Aliyah As'adiyah Putri Sengkang, yang cukup besar pengaruhnya terhadap keberhasilan pelaksanaan pendidikan dan pembelajaran adalah pendidik atau guru. Jumlah guru di Madrasah Aliyah As'adiyah Puteri Sengkang saat ini sebanyak 51 Orang dengan berbagai status, guru tetap yayasan, pegawai negeri sipil, dan guru tidak tetap. Kompetensi Pedagogik dengan kualifikasi akademik bagi guru Madrasah Aliyah (MA) sebagaimana diatur dalam Peraturan Menteri Pendidikan Nasional Nomor 10 Tahun 2007 Tentang Standar Kualifikasi Akademik dan Kompetensi Guru. Pada poin $d$ disebutkan bahwa:

"Guru pada SMA/MA atau bentuk lain yang sederajat harus memiliki kualifikasi akademik pendidikan minimum diploma empat (D-IV) atau sarjana (S1) program studi yang sesuai dengan mata pelajaran yang diajarkan/ampuh, dan diperoleh dari program studi terakreditasi."Berdasarkan hasil wawancara dengan Kepala Madrasah Aliyah As'adiyah Puteri Sengkang sebagai berikut:

Peneliti: bagaimana dengan guru yang mengajarkan pelajaran pendidikan Islam lantas tidak sesuai dengan latar belakang pendidikannya? Kepala Madrasah: "hal ini terjadi karena, dilingkungan Pondok Pesantren As'adiyah ada Pendidikan Tinggi Agama Islam, maka lulusannya ini kemudian direkrut menjadi pendidik, walau memang ada yang tidak sesuai dengan latar belakang pendidikannya. Misalnya, ada lulusan Program Studi Pendidikan Agama Islam tapi diberi tugas mengajarkan mata pelajaran Umum, misalnya Bahasa Indonesia, Sejarah Nasional, dan lain lain."

Berdasarkan dalam standar kompetensi guru pendidikan Islam pada Sekolah Umum dan Madrasah, yang diterbitkan Kementerian Agama RI, disebutkan tentang kompetensi guru Pendidikan Islam yang mengajar di Madrasah, termasuk Madrasah Aliyah, terdiri atas

${ }^{5}$ Tim Redaksi Nuansa Aulia, Himpunan Perundang-undangan RI. Tentang Sistem Pendidikan Nasional, (Cet. II; Bandung: Nuansa Aulia, 2008), h. 299.

${ }^{6}$ Wawancara, Dra. Rosmilah Shaleh (Kepala Madrasah Aliyah Puteri Sengkang), Pada tanggal 14 April 2018 di Sengkang. 
beberapa kompetensi, yakni kompetensi Utama yaitu kemampuan akademik, kemampuan menciptakan suasana belajar yang kondusif dan kompetensi pendukung yaitu kemampuan membangun hubungan dan komunikasi, kemampuan kepemimpinan, kemampuan dalam mengembangkan diri.

Seperti yang telah dikemukakan pada pembahasan sebelumnya, bahwa salah satu kompetensi inti yang harus ada pada setiap guru, termasuk guru di Madrasah Aliyah As'adiyah Puteri Sengkang, adalah kompetensi pedagogik, yakni guru harus menguasai karakteristik peserta didik, baik dari aspek fisik, moral, emosional, dan spiritual serta intelektual. Sebagaimana hasil wawancara penulis dengan Kepala Madrasah Aliyah As'adiyah Puteri Sengkang bahwa: "kompetensi guru pendidikan Islam seperti ini, diperlukan agar guru tersebut, memiliki kemampuan untuk melakukan pengidentifikasian potensi yang dimiliki peserta didik, terutama mata pelajaran yang diampuh, mengidentifikasi bakat dan minat yang dimiliki, dan mendeteksi kesulitan belajar peserta didik."

Berdasarkan hasil wawancara tersebut, dapat dipahami bahwa kompetensi guru pendidikan Islam, yang berkaitan dengan tugas dan fungsinya sebagai pembelajar, guru hendaknya menguasai teori belajar dan prinsip kegiatan pembelajaran, dan mampu menerapkan berbagai pendekatan, strategi, metode, dan teknik pembelajaran yang mendidik secara kreatif dalam mata pelajaran yang diampuh.

Kompetensi guru Madrasah Aliyah As'adiyah Puteri Sengkang, dalam hal ini, kompetensi diperlukan bagi setiap guru, agar dalam menjalankan fungsi profesinya, dapat secara optimal. Karena dalam konteks masyarakat yang maju dan modern, profesi menuntut kemampuan membuat keputusan yang tepat dan kemampuan membuat kebijakan. Menurut kepala Madra sah Aliyah As'adiyah Puteri bahwa: "kompetensi guru diperlukan dalam rangka mengembangkan dan mendemonstrasikan prilaku pendidikan, bukan sekedar mempelajari keterampilan mengajar. Tetapi merupakan penggabungan dan aplikasi suatu keterampilan dan pengetahuan yang saling bertautan dalam bentuk prilaku nyata. Prilaku pendidikan harus pula ditunjang aspek lain, seperti menguasai bahan ajar, memahami teori kependidikan serta kemampuan mengambil keputusan yang adil berdasarkan nilai, sikap dan kepribadian."

Berdasarkan hasil wawancara tersebut, guru pendidikan Islam selain bertugas menyampaikan informasi kepada peserta didik, tentang ajaran dan nilai-nilai Islam, juga yang lebih penting adalah guru harus menjadi fasilitator yang membuka dan memberi ruang kemudahan kepada peserta didik, agar dapat belajar dalam suasana yang menyenangkan, gembira, penuh semangat, tidak cemas tetapi berani mengemukakan pendapat secara terbuka. Hal ini merupakan modal dasar peserta didik untuk tumbuh dan berkembang dan siap beradaptasi menghadapi berbagai suasana. Oleh karena itu, kompetensi guru harus berimplikasi langsung terhadap peserta didik.

${ }^{7}$ Wawancara, Dra. Rosmilah Shaleh (Kepala Madrasah Aliyah As'adiyah Puteri Sengkang), Pada tanggal 14 April 2018 di Sengkang.

${ }^{8}$ Wawancara, Dra. Rosmilah Shaleh (Kepala Madrasah Aliyah As'adiyah Puteri Sengkang), Pada tanggal 14April 2018 di Sengkang. 


\section{B. Guru dalam Pengelolaan Pembelajaran di Madrasah Aliyah As'adiyah Puteri Sengkang Kabupaten Wajo}

Guru dalam menjalankan tugasnya harus memiliki suatu kecakapan, kemampuan, dan memenuhi kualifikasi yang cukup dalam mendukung profesinya. Diantaranya adalah kompetensi pedagogik, kepribadian, profesional, dan sosial, tanpa mengabaikan salah satu kompetensi yang harus dimiliki oleh seorang guru.

Perencanaan merupakan langkah pertama dalam proses pembelajaran yang harus dilakukan oleh guru. Perencanaan merupakan proses yang sistematis dalam pengambilan keputusan tentang tindakan yang akan dilakukan pada waktu yang akan datang. Perencanaan pembelajaran di Madrasah Aliyah As'adiyah Puteri Sengkang, ditandai adanya kurikulum, Silabus, RPP (Rencana Pelaksanaan Pembelajaran), jadwal pembelajaran program semester, analisis pembelajaran, buku paket. Perangkat pembelajaran tersebut ada yang dibuat atau diadakan madrasah seperti kurikulum, silabus, jadwal pembelajaran, sedangkan RPP, buku paket, program semester, analisis program pembelajaran dan absensi peserta didik dibuat oleh guru kelas.

Hal ini senada dengan hasil wawancara penulis dengan Kepala Madrasah Aliyah As'adiyah Puteri Sengkang bahwa: "perangkat pembelajaran yang berkaitan langsung atau disusun oleh guru yang bersangkutan memang sudah diwajibkan untuk membuatnya, namun saat ini hampir semua guru, baik guru mata pelajaran maupun guru pendidikan Islam telah memiliki silabus, dan RPP serta kelengkapan lainnya.",9

Berdasarkan hasil wawancara tersebut, bahwa pengadaan perangkat pembelajaran tersebut, selain dimaksudkan untuk kelengkapan administrasi pendidikan dan pembelajaran, juga yang lebih penting, perangkat itu menjadi dukungan kuat untuk membangun kompetensi guru dalam rangka memajukan dan mengembangkan mutu pendidikan Islam, yang ditandai meningkatnya prestasi belajar peserta didik.

Ketika penulis menanyakan kepada Guru Bahasa Arab, Madrasah Aliyah As'adiyah Puteri Sengkang, tentang upaya dan langkah apa yang selama ini dilakukan untuk meningkatkan prestasi belajar peserta didik? mengatakan bahwa:"banyak aspek yang harus diperhatikan, selain melengkapi perangkat pembelajaran yang dibutuhkan untuk menunjang kegiatan pembelajaran, juga meningkatkan kompetensi guru, seperti selalu menerapkan metode pembelajaran yang bervariasi, menciptakan kerjasama dan komunikasi antara orang tua peserta didik dengan pihak madrasah, menciptakan pembelajaran yang menyenangkan, dan sebagainya."10

Berdasarkan obervasi penulis untuk mengidentifikasi guru yang ideal ada beberapa indikator yang dapat dijadikan ukuran karakteristik guru yang dinilai kompeten secara profesional, mampu mengembangkan tanggung jawab dengan baik, mampu melaksanakan

${ }^{9}$ Wawancara, Dra. Rosmilah Shaleh (Kepala Madrasah Aliyah As'adiyah Puteri Sengkang), pada tanggal 14 April 2018 di Sengkang.

${ }^{10}$ Wawancara, Dra. Hj. Rosdiana, HS, MM (Guru Bahasa Arab Madrasah Aliyah As'adiyah Puteri Sengkang), pada tanggal 15 April 2018 di Sengkang. 
peran dan fungsinya, mampu bekerja untuk mewujudkan tujuan pendidikan di sekolah, mampu melaksanakan peran dan fungsinya dalam pembelajaran, dan membuat laporan serta mengerjakan administrasi pendidikan.

Hasil wawancara penulis dengan Wakamad kurikulum Madrasah Aliyah As'adiyah Puteri Sengkang menjelaskan bahwa: "untuk mengetahui berhasil tidaknya peserta didik mencapai prestasi belajar harus diukur melalui proses penilaian, karena penilaian merupakan instrumen penting dalam kegiatan pembelajaran. Dengan tujuan; menelusuri agar proses pembelajaran berjalan sesuai dengan rencana. Dalam hal ini guru mengumpulkan informasi dan data sepanjang semester dan tahun pelajaran melalui berbagai bentuk penilaian kelas agar memperoleh gambaran tentang pencapaian kompetensi; pengecekan, artinya penilaian dilaksanakan untuk mengecek adakah kelemahan yang dialami peserta didik dalam belajar. Melalui penilaian kelas, baik yang bersifat formal maupun informal guru melakukan pengecekan kemampuan apa yang peserta didik telah kuasai dan apa yang belum."11

Berdasarkan hasil wawancara tersebut, bahwa penilaian yang dilaksanakan dengan maksud mengukur tingkat keberhasilan peserta didik dalam mata pelajaran atau kelas, harus disusun secara terencana dan sistematis oleh guru memiliki fungsi motivasi, belajar tuntas dan efektivitas pengajaran dan umpan balik. Penilaian kelas salah satu fungsinya adalah mendorong peserta didik untuk lebih giat belajar. Latihan, tugas dan ulangan yang diberikan oleh guru har`us memungkinkan peserta didik melakukan proses pembelajaran baik secara individual maupun kelompok. Bentuk latihan, tugas dan ulangan dirancang, sehingga peserta didik terdorong untuk terus belajar dan merasa kegiatan penilaian itu menyenangkan dan menjadi kebutuhannya. Dengan mengerjakan latihan, tugas, dan ulangan yang diberikan oleh guru, peserta didik memperoleh gambaran tentang hal-hal apa yang dia sudah lakukan atau dikuasai dan belum diketahuinya. Untuk menentukan hasil belajar dengan kompetensi guru, harus dilihat dalam berbagai dimensi, diantaranya kinerja guru. Diantara tanda-tanda kompetensi guru yang baik, adalah :

1. Disiplin kerja, datang dan pulang sekolah tepat waktu

2. Jarang sekali meninggalkan madrasah tanpa ada alasan yang jelas

3. Senantiasa melengkapi dirinya dengan sumber belajar, seperti penyiapan perangkat pembelajaran, mampu memanfaatkan media pembelajaran yang efektif.

4. Mencintai anak didiknya, bergaul dan berinteraksi secara proporsional, adil dan bijaksana.

5. Merasa sedih jika ada peserta didik yang kurang berhasil dalam belajar.

Menurut penulis kelima sikap guru tersebut sangat besar pengaruhnya terhadap upaya peningkatan prestasi belajar peserta didik. Apakah semua guru di Madrasah Aliyah As'adiyah Puteri Sengkang sudah memiliki kompetensi yang sama, dari hasil pengamatan penulis memang ada sebagian guru Madrasah Aliyah As'adiyah Puteri Sengkang kurang apresiatif terhadap kemajuan peserta didik, bahkan ada guru kalau sudah menyajikan materi pembelajaran berdasarkan jam atau waktu di dalam kelas, kewajibannya seakan-akan sudah tidak ada lagi, ia hanya menyampaikan materi pembelajaran di hadapan peserta didik secara

${ }^{11}$ Wawancara, Zuheriyah, SH.i (Wakamad Kurikulum Madrasah Aliyah As'adiyah Putri Sengkang), pada tanggal 15 April 2018 di Sengkang. 
monoton, dan kalau sudah disampaikan, tidak ada lagi tindak lanjut, berhasil atau tidak menguasai kompetensi yang ditetapkan atau tidak, tidak lagi menjadi perhatian guru. Guru yang seperti ini diposisikan sebagai guru yang tidak memiliki rasa tanggungjawab dan kompetensi untuk memajukan pendidikan dan pembelajaran. Dalam konsep pendidikan sekarang, guru tidak hanya bertugas menyampaikan materi pembelajaran dihadapan peserta didik lalu tugasnya sudah selesai bila materi sudah disajikan, tetapi guru harus menjadi fasilitator yang bertugas memberikan kemudahan belajar, kepada semua peserta didik, agar dapat belajar dalam suasana menyenangkan, gembira, penuh semangat, tidak cemas, dan tidak merasa ditekan oleh guru di dalam kelas, tetapi peserta didik ditumbuhkan keberaniannya untuk mengemukakan pendapat. Rasa gembira penuh semangat, tidak cemas, tidak merasa tertekan, dan berani mengemukakan pendapat secara terbuka merupakan modal dasar bagi peserta didik Madrasah Aliyah As'adiyah Puteri Sengkang untuk tumbuh dan berkembang menjadi peserta didik yang berprestasi dalam arti luas.

Hal ini senada dengan hasil wawancara penulis dengan Kepala Madrasah Aliyah As'adiyah Puteri Sengkang mengatakan bahwa: "memang masih ada guru di Madrasah ini kurang peduli atas kemajuan pendidikan dan prestasi belajar peserta didik, ia hanya menjalankan tugas dan fungsinya secara monoton, tanpa inovasi dan kreativitas, seperti menggunakan media pembelajaran, menetapkan metode pembelajaran yang bervariasi dan lain sebagainya. Sikap guru seperti ini bila dibiarkan akan menghambat proses pencapaian hasil belajar. Oleh karena itu, terus menerus bersama dengan pengawas pendidikan, untuk melakukan pembinaan, baik tekhnis administrasi maupun pelaksanaan pembelajaran." 12

Berdasarkan hasil observasi penulis, bahwa guru sebagai fasilitator, tugas guru yang paling utama adalah membuka dan memberi kemudahan belajar, bukan hanya menceramahi, atau mengajar, apalagi menghajar peserta didik, bukanlah sistem mendidik, saat ini diperlukan guru yang demokratis, jujur, terbuka, serta siap menerima kritikan dari orang lain, termasuk kritikan dari peserta didik itu sendiri. Disinilah pentingnya pembelajaran terpadu, yang digunakan sebagai modal pembelajaran yang dapat membangkitkan motivasi peserta didik. Untuk itu, guru sebagai komponen pendidikan yang paling esensial keberadaannya terhadap keberhasilan proses pembelajaran.

Berdasarkan hasil observasi penulis, efektivitas lebih berkaitan dengan perbandingan antara pencapaian tujuan dengan rencana yang telah disusun, atau antara perbandingan hasil kongkrit dengan hasil perencanaan. Efektivitas pengelolaan pembelajaran pendidikan Islam, bagaimana kegiatan itu dilihat berdasarkan teori sistem dan dimensi waktu. Oleh karena itu efektifnya suatu perencanaan pembelajaran sangat tergantung guru untuk melaksanakan tugas sebagai pendidik dalam melayani kebutuhan peserta didik, serta desain pembelajaran yang sudah dirumuskan. Indikator suatu kegiatan efektif apabila peserta didik mampu memahami, mengetahui, dan mengambil sikap atas kompetensi yang dikuasai menjadi milik peserta didik lalu diwujudkan dalam tindakan.

Guru Fiqih Madrasah Aliyah As'adiyah Puteri Sengkang, menjelaskan bahwa:

${ }^{12}$ Wawancara, Dra. Rosmilah Shaleh (Kepala Madrasah Aliyah As'adiyah Puteri Sengkag) pada tanggal 14 Maret 2018 di Sengkang. 
"untuk mengefektifkan kompetensi guru pendidikan Islam, diperlukan beberapa langkah, antara lain: prosedur pembelajaran, pendekatan, metode, teknik mengajar, dan lain-lain."13

Berdasarkan hasil observasi penulis, dari segi prosedur pembelajaran hal ini telah dipraktekkan di Madrasah Aliyah As'adiyah Puteri Sengkang yang dilihat dalam perspektif administrasi atau perangkat pembelajaran, karena telah dibuat seperti RPP, analisis program pembelajaran dan jadwal pembelajaran serta sistem penilaian. Sedangkan dari segi metode pembelajaran, dari catatan dan hasil observasi penulis terhadap aktivitas kompetensi guru pendidikan Islam, dominan menerapkan metode pembelajaran ceramah. Guru belum mampu memvariasi metode pembelajaran, sehingga cara penyampaian materi bersifat monoton, kaku dan tradisional. Alasan guru menggunakan metode ceramah harus benar-benar dapat dipertanggungjawabkan. Metode ceramah diterapkan karena pertimbangan: (1) peserta didik memerlukan penjelasan; (2) benar-benar tidak ada sumber belajar yang bisa dipergunakan kecuali ceramah; (3) jika peserta didik di dalam kelas terlalu banyak maka yang tepat adalah metode ceramah. Jadi, metode pembelajaran yang dikembangkan oleh guru pendidikan Islam di Madrasah Aliyah As'adiyah Puteri Sengkang ini dominan adalah metode ceramah. Salah satu kompetensi yang harus dimiliki guru, khususnya guru pendidikan Islam adalah kemampuan mengelola pembelajaran. Seperti diketahui bahwa dalam proses pembelajaran selain diawali dengan perencanaan pembelajaran yang jelas dan bijak, serta didukung dengan komunikasi yang baik, juga harus didukung dengan penerapan strategi, sehingga peserta didik terlibat secara aktif dalam kegiatan pembelajaran. Pengelolaan pembelajaran merupakan suatu proses penyelenggaraan interaksi peserta didik dengan guru dan sumber belajar pada satu lingkungan belajar. Pusat pengelolaan pembelajaran adalah peserta didik itu sendiri. Oleh karena itu, kemampuan guru untuk mengelola pembelajaran senantiasa berorientasi pada kepentingan peserta didik. Guru harus terampil mengatur dan merekayasa segala sesuatu. Guru dapat mengatur peserta didik berdasarkan situasi ketika proses pembelajaran berlangsung.

Hal ini senada dengan hasil wawancara penulis dengan Guru Bahasa Arab Madrasah Aliyah As'adiyah Puteri Sengkang bahwa:"kompetensi guru dalam pengelolaan pembelajaran salah satunya adalah pengaturan terhadap peserta didik, yakni melakukan pengelompokkan atas peserta didik. Pengelompokkan dilakukan oleh guru dalam rangka memperlancar proses pembelajaran, misalnya mengelompokkan peserta didik berdasarkan rencana tugas yang akan diberikan oleh guru, untuk digunakan sebagai sarana bagi guru untuk memberi tugas untuk dikerjakan bagi peserta didik dalam waktu yang sama."14

Selain kemampuan mengelola peserta didik, juga setiap guru dituntut untuk mampu dan cakap berinteraksi denga guru yang lain, karena mata pelajaran yang diajarkan oleh setiap guru ada dan berhubungan dengan mata pelajaran yang lain. Oleh sebab itu, guru dituntut mengembangkan kepribadiannya, seperti kemampuan mengimplementasikan ilmu yang dimiliki kepada peserta didik secara optimal. Dalam hal ini, guru berkewajiban mengamalkan ilmunya, menyatukan antara ucapan dan perbuatan, sebab ilmu itu diketahui dengan mata

\footnotetext{
${ }^{13}$ Wawancara, Dra. Aidah Latif, S.Pd.I (Guru mata pelajaran Fikhi Madrasah Aliyah As'adiyah Puteri Sengkang), pada tanggal 15 April 2018 di Sengkang.

${ }^{14}$ Wawancara, Dra. Hj. Rosdiana, HS, MM, (Guru Mata Pelajaran Bahasa Arab di Madrasah Aliyah As'adiyah Puteri Sengkang), pada tanggal 3 Mei 2018 di Sengkang.
} 
batin, sedangkan amal perbuatan diketahui dan disaksikan dengan mata lahir. Sementara pandangan orang lain, selalu melihat dalam persepektif lahir. Dalam mengamalkan atau mengajarkan ilmunya kepada peserta didik, guru harus bersikap kasih sayang terhadap peserta didik, bersikap toleran dan pemaaf. Dalam arti guru harus bersikap positif terhadap peserta didik lapang dada, dan menjaga serta memelihara suasana yang lebih kondusif, sehingga tercipta suasana belajar yang menyenangkan.

Kegiatan pembelajaran mencerminkan bahwa pembelajaran pendidikan Islam tidak sesederhana dalam proses penyampaiannya tetapi pendidikan Islam lebih berorientasi pada pembentukan karakter dan akhlak mulia, serta kepribadian peserta didik. Oleh karena itu, pengembangan pembelajaran mata pelajaran pendidikan Islam memerlukan model pembelajaran yang sesuai dengan tuntutan isi dan hasil yang diharapkan, dan perlu guru memperhatikan prinsip yang mendukung pelaksanaan pembelajaran. Sebagai guru mata pelajaran pendidikan Islam, maka dituntut senantiasa merujuk pada tuntunan ajaran Islam, sebagaimana dicontohkan oleh Rasulullah saw., segala ucapan guru mempunyai kekuatan yang dapat menjadi dorongan dan motivasi bagi peserta didik, ucapannya ringkas, sehingga dapat memberikan waktu bagi peserta didik untuk memahami dan mengembannya. Selain sikap kepribadian guru yang disebutkan di atas menjadi kompetensi baginya juga yang harus diperhatikan adalah guru memahami prosedur pembelajaran. Semua kegiatan guru adalah untuk peserta didik sepenuhnya. Oleh karena itu, guru harus mengetahui perbedaan karakter setiap peserta didik, lalu melakukan desain pembelajaran berdasarkan perbedaan karakter sikap, dan minat peserta didik. Implementasi sebuah prosedur pembelajaran, antara lain:

\section{Pendekatan Pembelajaran}

Pendekatan pembelajaran merupakan salah satu aspek prosedur pembelajaran yang harus dikuasai dan dikembangkan oleh guru, sebagai kompetensi dasarnya sebagai pendidik, pengajar, penilai dan pelatih.

Proses pembelajaran merupakan interaksi yang dilakukan antara guru dengan peserta didik dalam suatu sistem pengajaran untuk mewujudkan tujuan pembelajaran. Berbagai pendekatan yang dipergunakan dalam kegiatan pembelajaran agama Islam harus dijabarkan ke dalam metode pembelajaran yang bersifat urgen. Penerapan metode pembelajaran berkaitan dengan kemampuan guru mengelola kelas, yakni menciptakan iklim belajar yang kondusif, dan mengendalikannya jika terjadi gangguan belajar. Keterampilan mengelola kelas lebih merupakan prinsip dasar. Dengan kata lain, kemampuan mengelola kelas oleh guru merupakan salah satu kompetensi yang harus dikembangkan.

\section{Mengelola Kelas}

Pengelolaan kelas lebih merupakan implementasi dari pengelolaan pembelajaran, di Madrasah Aliyah As'adiyah Puteri Sengkang guru pendidikan Islam, sebenarnya telah menerapkan dan melaksanakan kegiatan pengelolaan kelas, akan tetapi efektivitasnya terhadap peserta didik masih perlu ditingkatkan, dalam arti pengelolaan kelas yang dilaksanakan oleh guru di Madrasah ini, belum optimal masih diperlukan langkah yang bersifat praktis. Keterampilan mengelola kelas memiliki komponen, 
sebagaimana dijelaskan oleh guru Aqidah Akhlak Madrasah Aliyah As'adiyah Puteri Sengkang, bahwa:"dalam mengelola kelas, antara lain kompenennya yang harus diperhatikan oleh guru adalah membuat perencanaan mengajar. Perencanaan pembelajaran merupakan tugas utama guru dan merupakan realisasi dari pengalaman belajar peserta didik yang telah ditetapkan pada tahapan penentuan pengalaman belajar. Guru dapat mengembangkan rencana pembelajaran dalam berbagai bentuk. Oleh karena itu, guru diberi kewenangan secara luas untuk menganalisis silabus sesuai dengan karakteristik dan kondisi madrasah."15

Menurut Guru al-Qur'a>n Hadi $\}$ s Madrasah Aliyah As'adiyah Puteri Sengkang, bahwa:"untuk pendekatan pembelajaran pendidikan Islam di Madrasah ini, ditempuh pendekatan yaitu: (1) Pendekatan keimanan dan pengamalan, yaitu mendorong peserta didik untuk melaksanakan shalat lima waktu, dzikir pagi dan tadarrus setiap hari diaula Madrasah Aliyah As'adiyah Puteri sebelum masuk kelas, (2) pendekatan emosional, yaitu menggugah perasaan dan emosi peserta didik agar menghayati ajaran Islam, sehingga lebih terkesan dalam jiwa peserta didik nilai-nilai ajaran Islam tersebut, (3) pendekatan fungsional, pendekatan yang dimaksudkan agar peserta didik merasakan manfaat dari pelaksanaan ajaran Islam yang selama ini dikerjakan." 16

Hal ini senada dengan hasil wawancara penulis dengan Kepala Madrasah Aliyah As'adiyah Puteri Sengkang, mengatakan bahwa:

"secara umum, metode pembelajaran diterapkan oleh guru dominan metode ceramah, serta divariasi dengan metode penugasan kepada peserta didik, dalam bentuk tugas di rumah. Sedangkan strategi pembelajaran terlihat dari persiapan guru yakni adanya RPP (Rencana Pelaksanaan Pembelajaran). Perangkat pembelajaran ini mencerminkan adanya strategi pembelajaran yang akan dilaksanakan oleh guru." 17

\section{Faktor Pendukung dan Penghambat Kompetensi Guru Pendidikan Islam dalam Pengelolaan Pembelajaran di Madrasah Aliyah As'adiyah Puteri Sengkang Kabupaten Wajo.}

Kompetensi utama guru pendidikan Islam, yakni kompetensi pedagogik, kepribadian, profesional, kompetensi sosial, dan kepemimpinan. Bila kompetensi tersebut dimiliki oleh setiap guru pendidikan Islam, kemudian diimplementasikan dengan baik, akan berimplikasi terhadap peserta didik. Kompetensi guru dalam mengelola pembelajaran perlu mendapat perhatian serius, hal ini penting karena pendidikan dinyatakan kurang berhasil, jika aspek kompetensi terabaikan dalam proses pendidikan dan pembelajaran. Kompetensi guru pendidikan Islam, akan efektif jika

${ }^{15}$ Wawancara, Dra. Hj. ST. Aisyah, (Guru Mata Pelajaran Aqidah Akhlak di Madrasah Aliyah As'adiyah \{Putri Sengkang), pada tangal 15 juli 2018 di Sengkang.

${ }^{16}$ Wawancara, St. Jazila, S.Pd.I, (Guru Qur'an Hadits Madrasah Aliyah As'adiyah Puteri Sengkang Kab.Wajo), pada tanggal 3 Mei 2018 di Sengkang.

${ }^{17}$ Wawancara, Dra Rosmilah Shaleh, (Kepala Madrasah Aliyah As'adiyah Puteri Sengkang), pada tanggal 3 Mei 2018 di Sengkang. 
pengelolaan pembelajaran lebih baik, seperti perencanaan yang matang, pelaksanaan yang efektif, dan ada pengendalian. Perencanaan pembelajaran oleh guru, artinya memperkirakan yang akan dicapai. Perencanaan berfungsi sentral dari manajemen pembelajaran dan berorientasi dimasa depan.

Minat, bakat, dan kemampuan potensi yang dimiliki peserta didik tidak akan berkembang secara optimal tanpa bantuan guru. Dalam kaitan ini, guru memperlihatkan peserta didik secara individual, karena antara satu peserta didik dengan yang lain, memiliki karakter yang berbeda. Kemampuan guru mengelola pembelajaran, artinya mengajar peserta didik secara sistematis, terarah, dan fokus, sehingga kegiatan pembelajaran bisa lebih efektif dan efisien. Untuk mewujudkan dan mengimplementasikan kompetensi guru pendidikan Islam sebagaimana dikemukakan sebelumnya, tentu dipengaruhi banyak hal. Mengimplementasikan kemampuan kompetensi guru mata pelajaran pendidikan Islam di Madrasah Aliyah As'adiyah Puteri Sengkang Kabupaten Wajo, dalam kaitannya dengan pengelolaan pembelajaran diperlukan suatu langkah strategis dan bersifat praktis. Komponen kompetensi pengelolaan pembelajaran, mencakup empat aspek utama, yaitu;

1. Penyusunan Rencana Pelaksanaan Pembelajaran (RPP)

2. Pelaksanaan interaksi kegiatan proses pembelajaran

3. Penilaian hasil belajar terhadap peserta didik

4. Tindak lanjut hasil pelaksanaan pembelajaran

Penyusunan Rencana Pelaksanaan Pembelajaran (RPP) disusun oleh guru mata pelajaran pendidikan Islam, yang menggambarkan rencana pembelajaran dan prosedur serta manajemen pembelajaran untuk mencapai satu atau lebih kompetensi dasar yang ditetapkan dalam standar isi dan dijabarkan dalam silabus. RPP merupakan komponen penting dari kurikulum, paling utama terkait dengan RPP adalah menjabarkan silabus ke dalam RPP yang telah operasional dan rinci, serta siap dijadikan pedoman pembelajaran. Pada pengembangan RPP guru mata pelajaran pendidikan Islam diberi kebebasan, untuk mengubah, memodifikasi dan menyesuaikan silabus dengan kondisi sekolah.

Berdasrkan observasi penulis, pelaksanaan interaksi pembelajaran, yang dilakukan oleh guru mata pelajaran pendidikan Islam di Madrasah Aliyah As'adiyah Puteri Sengkang Kabupaten Wajo, dilaksanakan sesuai dengan jadwal pelajaran yang telah disusun oleh Madrasah. Penyajian materi pelajaran pendidikan Islam di Madrasah Aliyah As'adiyah Puteri Sengkang dilaksanakan di kelas. Setiap kelas, mulai kelas X sampai dengan XII menerima materi pelajaran. Untuk menyampaikan materi pelajaran ini, guru menempuh tiga langkah yaitu:

1. Pendahuluan pembelajaran kegiatan yang dilakukan antara lain:

a. Guru mengucapkan salam, peserta didik menjawab salam

b. Guru mengecek nama-nama peserta didik di kelas 
c. Membuka interaksi pembelajaran dengan menghubungkan hasil pembelajaran pertemuan yang lalu.

2. Kegiatan inti pembelajaran, dalam hal ini guru menyajikan materi pembelajaran dengan berpedoman pada RPP, dan buku paket yang digunakan, menggunakan metode pembelajaran yang bervariasi.

3. Kegiatan akhir pembelajaran, pada kegiatan ini diberikan ujian atau tes akhir pembejaran.

Mengimplementasikan keempat aspek pengelolaan pembelajaran tersebut, tentu tidaklah gampang, tetapi ada sejumlah faktor, baik faktor pendukung maupun faktor penghambat.

1. Faktor pendukung

Mengimplementasikan kemampuan kompetensi guru mata pelajaran pendidikan Islam di Madrasah Aliyah As'adiyah Puteri Sengkang Kabupaten Wajo, dalam kaitannya dengan pengelolaan pembelajaran diperlukan suatu langkah strategis dan bersifat praktis. Seperti yang telah disebutkan bahwa guru mata pelajaran pendidikan Islam di Madrasah Aliyah As'adiyah Puteri Sengkang merupakan pengembang kurikulum yang akan menerjemahkan, menjabarkan, dan mentransformasikan nilainilai yang terdapat dalam kurikulum mata pelajaran pendidikan Islam. Dalam hal ini, tugas guru tidak hanya mentrasnfer ilmu pengetahuan, tetapi lebih dari itu, mengajarkan peserta didik supaya dapat berpikir integral mencapai makna. Kegiatan tersebut bukan hanya berwujud pembelajaran di kelas, tetapi dapat berwujud kegiatan lain, seperti bimbingan belajar kepada peserta didik. Untuk melaksanakan dan merealisasikan tugas dan fungsi tersebut guru mata pelajaran pendidikan Islam di Madrasah Aliyah As'adiyah Puteri Sengkang perlu mendapat dukungan dari semua komponen madrasah, seperti kepala madrasah, wali kelas, peserta didik itu sendiri, orang tua, dan sejumlah perangkat pendidikan yang lain, sehingga semua komponen berjalan sehingga pelaksanaan pengelolaan pembelajaran berjalan secara efektif.

2. Faktor penghambat

Faktor penghambat adalah sesuatu yang menyebabkan kegiatan pengelolaan pembelajaran untuk mata pelajaran pendidikan Islam di Madrasah Aliyah As'adiyah Puteri Sengkang kurang optimal pelaksanaannya. Ada beberapa faktor yang terjadi dalam lingkungan Madrasah Aliyah As'adiyah Puteri Sengkang menyebabkan pengelolaan pembelajran kurang optimal, antara lain:

a. Perangkat pembelajaran, di Madrasah Aliyah As'adiyah Puteri Sengkang ini perangkat pembelajaran relatif memadai untuk mendukung kegiatan pengelolaan pembelajaran tetapi belum optimal dipergunakan oleh guru mata pelajaran pendidikan Islam artinya perangkat pembelajaran tersebut kurang dimaksimalkan penggunaannya.

b. Hubungan dan kerjasama antara guru mata pelajaran pendidikan Islam dengan guru kelas, belum sejalan dalam menerapkan suatu aturan baik yang berhubungan 
dengan peserta didik maupun aturan internal Madrasah, sehingga dapat menimbulkan persepsi yang berbeda dari kalangan peserta didik sendiri.

Kedua faktor penghambat tersebut mempengaruhi kinerja guru mata pelajaran pendidikan Islam dalam proses pembelajaran. Oleh karena itu, diperlukan langkah untuk mengatasi faktor penghambat tersebut.Hal ini senada dengan hasil wawancara penulis dengan guru Bahasa Arab Madrasah Aliyah As'adiyah Puteri Sengkang bahwa:"faktor penghambat dalam pengelolaan pembelajaran dari segi sarana dan prasarana dalam hal kemajuan teknologi saat ini, tingkat pemahaman peserta didik yang berbeda-beda, sehingga proses pembelajaran terkadang belum memenuhi kompetensi yang ingin dicapai. Kemudian dari segi jam mengajar sangat dibatasi oleh waktu, terkadang ada guru yang terlambat masuk sehingga mengambil jam pelajaran guru selanjutnya yang akan mengajar.,"18

Ketika penulis menanyakan kepada guru Bahasa Arab, bagaimana cara ibu mengatasi faktor yang menghambat pengelolaan pembelajaran? Guru bahasa arab mengatakan bahwa: "dalam mengatasi faktor yang menghambat dalam mengelola pembelajaran di kelas, dari segi waktu, guru harus menggunakan secara efektif waktu yang diberikan dalam proses pembelajaran, kemudian bagi peserta didik yang kurang memahami pelajaran tersebut, peserta didik ini di arahkan untuk dibimbing dengan teman yang sudah paham dengan pelajaran terssebut.

\section{KESIMPULAN}

Berdasarkan hasil analisis dan pembahasan penelitian yang telah dikemukakan pada bab-bab sebelumnya, maka dapat disimpulkan sebagai berikut:

1. Kompetensi guru pendidikan Islam di Madrasah Aliyah As'adiyah Puteri Sengkang Kabupaten Wajo, belum maksimal, yang berkaitan dengan tugas fungsinya sebagai guru hendaknya menguasai teori belajar, prinsip kegiatan pembelajaran, dan mampu menerapkan berbagai pendekatan, strategi, metode, serta teknik pembelajaran yang mendidik secara kreatif dalam mata pelajaran yang diampuh.

2. Guru pendidikan Islam dalam pengelolaan pembelajaran di Madrasah Aliyah As'adiyah Puteri Sengkang Kabupaten Wajo, masih diperlukan efektifitas yang lebih optimal agar keberhasilan pembelajaran dapat tercapai dengan baik dan operasional guru mata pelajaran pendidikan Islam, terlihat dari upaya guru untuk melaksanakan perencanaan, pelaksanaan dan evaluasi terutama yang berkenaan dengan perangkat pembelajaran, diperlukan model pembelajaran sesuai dengan tuntutan isi dan hasil yang diharapkan.

3. Faktor pendukung guru pendidikan Islam dalam pengelolaan pembelajaran di Madrasah Aliyah As'adiyah Puteri Sengkang yaitu ketersediaan perangkat

\footnotetext{
${ }^{18}$ Wawancara, Dra. Hj. Rosdiana, HS, MM, (Guru Mata Pelajaran Bahasa Arab di Madrasah Aliyah As'adiyah Puteri Sengkang), pada tanggal 3 Mei 2018 di Sengkang.
} 
pembelajaran, prasarana Madrasah, dan fungsi yang mendukung kegiatan pembelajaran. Faktor penghambat guru pendidikan Islam dalam pengelolaan pembelajaran di Madrasah Aliyah As'adiyah Puteri Sengkang yaitu keterbatasan jam pelajaran, kedisiplinan guru dan sarana belajar Madrasah.

\section{DAFTAR PUSTAKA}

al-Qur'a>n Al-Kari>m

al-Nahd \}awi Abdurrahman, Pendidikan Islam di Rumah, Sekolah dan Masyarakat. Cet. IV; Jakarta: Gema Insani, 2004.

al-Ghazali, Ringkasan Ihya' Ulumuddin, Jakarta: Pustaka Amani, 1995.

As'ad Muhammad, "Pondok Pesantren As'adiyah" dalam Al Qalam, Balai Penelitian dan Pengembangan Agama Makassar, Volume 15, 2000.

Asep Djihaddan Suyanto, Bagaimana Menjadi Calon Guru dan Guru Profesional. Cet. II; Yogyakarta: Multi Pressindo, 2013.

Asradan Sumiati, Metode Pembelajaran. Cet. II; Bandung: CV. Wacana Prima, 2008.

Bungin Burhan, Analisis Data Kualitatif. Cet. III; Jakarta: Rajawali Press, 2009.

Damopolii Muljono, Pesantren Moderen IMMIM Pencetak Muslim Modern. Cet. I; Jakarta: Rajagrafindo Persada, 2011.

Danim Sudarwan, Profesionalisasi dan Etika Profesi Guru. Cet. III; Bandung: Alfabeta, 2013.

Darajat Z|akiyah, Metodik Khusus Pengajaran Agama Islam. Cet. II; Jakarta: PT. BumiAksara, 1995.

, Pendidikan Islam dalam Keluarga dan Sekolah. Cet.II; Jakarta: Ruhama, 1995.

Emzir, Metodologi Penelitian Pendidikan: Kuantitatif dan Kualitatif. Cet. VI; Jakarta: Rajagrafindo Persada, 2012.

Fahimah Husnul Ilyas dan Malik Abdul, Warisan Intelektual Sang Maha Guru K.H.Muhammad As'ad. Cet. I; Solo: Zadahaniva Publishing, 2017.

Getteng Rahman Abd., Menuju Guru Profesional dan ber-Etika. Cet. VIII; Yogyakarta: Graha Guru, 2012.

Hamalik Oemar, Pendidikan Guru Berdasarkan Pendekatan Kompetensi. Cet.IV; Jakarta: BumiAksara, 2006.

Imam Machali dan Ara Hidayat, Pengelolaan Pendidikan. Bandung: Pustaka Educa, 2010 . 
Jala>1 Fatah\} Abdul, Min Us\}uli al-Tarbawiyah fi> al-Islam. Mesi>r: Dar al-Kutub alMisyriyah\}, 1977.

Kafrawi, Pembaharuan Sistem Pendidikan Pondok Pesantren. Cet. III; Jakarta: Cemarah Indah, 1978.

Kementerian Agama RI, Standar Kompetensi Guru Pendidikan Agama Islam Pada Sekolah Umum Madrasah. Cet. I; Jakarta: Dirjen Kelembagaan Agama Islam, 2004.

Kementerian Agama RI, Al-Qur'a>n dan Terjemahnya. Bekasi: PT. Ikrar Mandiri Abadi, 2016.

Komaruddin, Kamus Istilah Skripsi dan Tesis. Bandung: Angkasa, 1999.

Kunandar, Guru Profesional. Jakarta: Raja Grafindo Persada, 2007.

Langgulung Hasan, Asas-asas Pendidikan Islam. Cet. II; Jakarta: Pustaka Al-Husna, 1988.

Maji >d Abdul, Perencanaan Pembelajaran. Cet. IV; Bandung: PT. Remaja Rosda Karya, 2009.

Marimba D. Ah\}mad, Pengantar Filsafat Pendidikan Islam. Cet. VIII; Bandung: PT. Alma'arif, 1989.

Marzuki, Metodologi Riset. Yogyakarta: t. pn, 2008.

Muh \}aimin, Paradigma Pendidikan Islam Upaya Mengefektifkan Pendidikan Agama Islam di Sekolah. Cet. II; Bandung: PT. Remaja Rosda Karya, 2002.

, Pengembangan Kurikulum Pendidikan Agama Islam di Sekolah, Madrasah dan Perguruan Tinggi. Cet. I; Jakarta: PT. Raja Grafindo Persada, 2008.

---------------, Wacana Pengembangan Pendidikan Islam. Cet. II; Surabaya: Pusat Studi Agama, Politik dan Masyarakat, 2004.

Muhajir Neong, Metodologi Penelitian Kualitatif. Cet. VIII; Yogyakarta: Rake Selatan, 1998.

Mulyasa H. E., Standar Kompetensi dan Sertifikasi Guru. Cet. IV; Bandung: PT. Remaja Rosda Karya, 2009.

--------------, Standar Kompetensi Sertifikasi Guru. Cet.I; Bandung: PT. Remaja Rosdakarya, 2007.

Kurikulum Berbasis Kompetensi. Cet. VI; Bandung: PT. Remaja Rosda Karya, 2004. 
, Manajemen Berbasis Sekolah Konsep, Strategi dan Implementasi. Cet. XII; Bandung: PT. Remaja Rosda Karya, 2009.

-----------, Standar Kompetensi dan Sertifikasi Guru. Cet. IV; Bandung: PT. Remaja Rosda Karya, 2009.

, Menjadi Kepala Sekolah Profesional. Bandung: PT. Remaja Rosdakarya, 2005.

N. K Roestiyah, Masala-masalah Ilmu Keguruan. Cet. III; Jakarta: Bina Aksara, 1989.

Nahd \}awi Al Abdurrahman, Pendidikan Islam di Sekolah, Rumah dan Masyarakat. Cet. IV; Jakarta: Gema Insani, 2004.

Nasir Ridlawan H. M., Mencari Tipologi Format Pendidikan Ideal Pondok Pesantren di Tengah Arus Perubahan. Cet. II; Yogyakarta: Pustaka Pelajar, 2010.

Nasution S., Metode Research. Jakarta: Bumi Aksara, 2007.

Nata Abuddin, Manajemen Pendidikan: Mengatasi Kelemahan Pendidikan Islam di Indonesia. Cet. III; Jakarta: Kencana Prenada Media, 2008.

--------------, Sejarah Pendidikan Islam. Cet. III; Jakarta: Rajawali Pers, 2012.

Ni'man Asrorun, Membangun Profesionalitas Guru. Cet. I; Jakarta: eLSAS, 2006.

Purwanto Ngalim M., Administrasi dan Supervisi Pendidikan. Cet. VI; Bandung: PT. Remaja Rosda Karya, 1993.

Republik Indonesia, Peraturan Pemerintah RI Nomor 19 Tahun 2005 Tentang Standar Nasional Pendidikan. Cet. I; Jakarta: Sinar Grafika, 2005.

, Peraturan Pemerintah RI. Nomor 19 Tahun 2005 tentang Standar Nasional Pendidikan. Cet. II; Jakarta: Sinar Grafika, 2007.

--------------, Undang-Undang Republik Indonesia Nomor 14 Tahun 2005 tentang Guru dan Dosen. Cet. VII; Jakarta: Sinar Grafika Offset, 2014.

, Undang-undang RI Nomor 14 Tahun 2005 Tentang Guru dan Dosen. Cet. I; Jakarta: Sinar Grafika, 2005.

Rivai Veitzal, Kepemimpinan dan Perilaku Organisasi. Jakarta: PT. Raja Grafindo Persada, 2007.

RosyadaDede, Paradigma Pendidikan Demokratis. Jakarta: Prenada Media, 2004.

Ruslan Muhammad dan Santing Waspada, Ulama Sulawesi Selatan: Biografi Pendidikan dan Dakwah. Cet. XVI: Makassar; Komisi Informasi dan Komunikasi MUI Sulawesi Selatan, 2007. 
Samana, Profesionalisme Keguruan. Cet. I; Yogyakarta: Kanisius, 1994.

Setiyadi BambangAg., Metode Penelitian untuk Pengajaran Bahasa Asing: Pendekatan Kuantitatif dan Kualitatif . Yogyakarta: Graha Ilmu, 2006.

S \}aleh Rachman Abdul, Pendidikan Agama dan Pembangunan Watak Bangsa. Cet. I; Jakarta: PT. Raja GrafindoPersada, 2005.

Sudjana Nana, Dasar-dasar Proses Belajar Mengajar. Bandung: SinarBaru, 1989.

Sugiyono, Metode Penelitian Kualitatif, kualitatif dan R\&D. Cet. XI; Bandung: Alfabeta, 2010.

, Metode Penelitian Pendidikan Pendekatan Kualitatif, Kuantitatif, dan $R \& D$. Bandung: Alfabeta, 2008.

Sukmadinata, Metode Penelitian Pendidikan. Cet. I; Bandung: Rosdakarya, 2006.

Suprihatiningrum Jamil, Guru Profesional. Cet.I; Jogjakarta: Ar-Ruzz Media, 2013.

SutisnaOtang, Administrasi Pendidikan Dasar Teoretis untuk Praktek Profesional. Cet. I; Bandung: Angkasa, 1989.

Tafsir Ah\}mad, Ilmu Pendidikan dalam Perspektif Islam. Cet. I; Bandung: PT. Remaja Rosda Karya, 1992.

Tim Penyusun Kamus, Kamus Besar Bahasa Indonesia. Cet.II; Jakarta: PN. Balai Pustaka, 1989.

Tim RedaksiAulia, Himpunan Perundang Undangan RI tentang Sistem Pendidikan Nasional. Cet. I; Bandung: NuansaAulia, 2008.

Uno B. Hamz|ah, Profesi Kependidikan. Cet. VI; Jakarta: BumiAksara, 2010.

Usman Uzer Moch., Menjadi Guru Profesional. Cet.XVII; Bandung: PT. Remaja Rosdakarya, 2005.

Wahyudi Imam, Panduan Lengkap Uji Sertifikasi Guru. Jakarta: Prestasi Putrakarya, 2012.

Wankel Charlesh dan Stoner James A.F., Management, Terj. Wilhelmus W. Bakowatun “Manajmen”. Cet. I; Jakarta: Intermedia, 1986.

Ya’qub Hamz\|ah, Menuju Keberhasilan Manajemen dan Kepemimpinan. Cet. I; Bandung: Diponegoro, 1984.

Yusuf MuriA., Metode Penelitiian. Cet. I; Jakarta: Prenadamedia Group, 2014.

Zainal Andi Arifin Dr. Mr., Wajo Abad XV-XVI Suatu Penggalian Sejarah Terpendam Sulawesi Selatan dari Lontara, tahun 1985. 